The Path of Love: Sufism in the Poetry of Daniel Abdal-Hayy Moore Radwa Ramadan Mahmoud

Department of English Language and Literature

Faculty of Women, Ain Shams University 


\begin{abstract}
This paper explores the concept of "Sufism" or "mysticism" (the two terms are used interchangeably herein) in the works of Daniel AbdalHayy Moore (1940 - 2016), an American Sufi poet, essayist, artist and playwright, who is referred to as "American Islam's Poet Laureate". The first part of the paper sheds light on the concept of "Sufism" or "Islamic mysticism" and highlights its central tenets. Using a theoretical framework informed by the Sufi theosophy of Ibn Arabi (1165-1240) and the writings of two important modern western scholars of Sufism, Annemarie Schimmel and William Chittick, the second part of the paper will study a selection of Moore's poems from his collections The Soul's Home (2014) and The Blind Beekeeper (2001). The aim of the paper is to show how Moore's poetry reveals the major concepts of Sufism. In this regard, Ibn Arabi's Sufi concepts act as a point of reference that helps clarify the interplay between the poems under study and Sufism.
\end{abstract}

\title{
Keywords
}

Mysticism, Sufism, Divine love, remembrance, Sufi poetry, Daniel Moore

\section{The Path of Love: Sufism in the Poetry of Daniel Abdal-Hayy Moore}

Daniel Abdal-Hayy Moore (1940-2016) is a distinguished American poet. He became a Sufi Muslim in 1970, changed his name to Abdal-Hayy; performed the Hajj in 1972; and lived and traveled widely throughout Morocco, Spain, Algeria and Nigeria. He then returned to California in the 1980s. In 2011, 2012 and 2014 he was a winner of the Nazim Hikmet Prize for Poetry. In 2013, he won an American Book Award, and in 2013 and 2014 was listed among The 500 Most Influential Muslims for his poetry. Moore was a protégé of the American poet Lawrence Ferlinghetti and of Alan Ginsberg, among other City Lights celebrities. He had his first collection, Dawn Visions, published by Lawrence Ferlinghetti of City Lights Books, San Francisco, in 1964, and the second in 1972, Burnt Heart/Ode to the War Dead. He created and directed The Floating Lotus Magic Opera Company in Berkeley, California in the late 60s. He was a central figure in the Santa Barbara poetry movement and an organizer of the Santa Barbara Poetry Festival. He published numerous books of poetry that were illustrated with his own 
drawings, and his intricate collages became the cover art. He was the major editor for a number of works, including The Burdah of Shaykh Busiri, translated by Hamza Yusuf, and the poetry of Palestinian poet, Mahmoud Darwish, translated by Munir Akash.

Moore has been referred to as "American Islam's poet laureate". His poetry reflected a deep and abiding faith in Islam and a dedication to Sufism, the major expression of mysticism in Islam. Sufism began to develop noticeably in the United States during the 20th century as a result of both immigration and conversion. Various groups have settled in different parts of the country, in many instances around the tomb of a foundational figure. Some groups identify themselves as branches of major orders "transplanted" in the United States from the lands of their origins. (Renard Historical Dictionary of Sufism 313) Becoming Muslim was the great turning point in Moore's life. He was invited to meet Shaykh ibn al-Habib in Meknes. His visit to Morocco had the strongest and most abiding influence on the spirit of his poetic work. Moore says, "All the recitations of wird, Qur'an, adhan, and especially the constant singing of the beautiful teaching Diwan of Shaykh ibn al-Habib, [the Desire of Journeying Murids and the Gift to Wayfaring Gnostics] which they sang after meals, in circles in the mornings and the evenings had a great impact on his life." Moore states:

In his Diwan I saw poetry in its true function as a joining of beauty with truth. Here was poetry that had a spiritual reality to lead its reader...or singer to enlightenment as a vehicle for knowledge of Allah, and through His "minute particulars" (to use a phrase by William Blake), to know Him by His multifarious manifestations on earth and in the heavens. ("Words on My Life and Poetry")

Thus, Moore's poetic oeuvre is an indication of what Carl Sandburg referred to in The People, Yes (2015), "the endless yearnings of man for the Beyond" (285). This paper thus sheds light on this "yearning" as perceived in his Sufi poetry. For Moore, poetry is a way of connecting more deeply with the Divine. What defined his poetry are his otherworldliness and self-renunciation; these show as constant concerns in his poems, as will be revealed in the analysis below, as well as in his statements on poetry. For Moore, "the purpose of poetry is illumination, a form of remembrance (Dhikr) with transformative capabilities" (Cornell 
149). In The Soul's Home (2014), Moore emphasizes his "mission statement":

For me the province of poetry is a private ecstasy made public, and the social role of the poet is to display moments of shared universal epiphanies capable of healing our sense of mortal estrangement-from ourselves, from each other, from our source, from our destiny, from The Divine. (11)

This quotation clearly establishes both the mood and the direction of Moore's poetry, which is characterized by extreme devotion and a strong social commitment. For Moore, the purpose of poetry is to attain ecstasy and its ultimate aim is greater than the poet's private self. Moore highlights the social role of the poet and asserts that his duty is to show universal epiphanic moments.

Drawing on the philosophy of Sufism and Ibn Arabi's ideas, as a conceptual and theoretical framework, the paper provides a close reading of Moore's selected poems. Usually known as al-Shaykh al-Akbar "the greatest Master", Ibn Arabi (1165-1240) is the most influential Sufi author of later Islamic history. He experienced an extraordinary mystical 'unveiling' (Kashf) or 'opening or openings' (futuh or fath) at about the age of fifteen, which is mentioned in his famous account of his meeting with Averroes. He had a great role in enhancing theoretical issues of Islamic philosophy and theosophy and his writings had an immense impact throughout the Islamic world and beyond.

This paper explores the intimate connection between Moore's poetry and the principal tenets of Sufism such as the mystical path, Divine love, remembrance, suffering and transformation, with reference to other relevant beliefs found within the philosophy of Sufism. Poetic and religious features that distinguish Moore as a Sufi mystic will be stressed. Through the selected poems, the paper highlights the mystical path and the inner state of mystical love as presented in poetry. Moore, as the paper proves here, uses a plethora of symbols to reveal the depth of Sufi mysticism. Hence, the paper highlights the relationship between theme and mode of expression in his poetry.

\section{Mysticism and Sufism}

In her classic book Mystical Dimensions of Islam(1975), Annemarie Schimmel (one of the world's leading experts on Islamic 
literature and Sufism) defines mysticism as "the great spiritual current which goes through all religions" (3). It has been defined as "the consciousness of the One Reality" and "the passion for the Absolute" (3). In order to achieve this final goal, mystics have passed through different stages of being and consciousness until they have acquired the vision of the Truth. Schimmel points out that mysticism "contains something mysterious", not to be reached by ordinary means or by intellectual efforts; this is evident in the root common to "the words mystic and mystery, the Greek myein, 'to close the eyes."' (Mystical Dimensions 4) For Evelyn Underhill, Mysticism is the pursuit of "a spiritual and intangible quest, the finding of a 'way out' of illusion or a 'way back"' to absolute Truth. It is an intimate personal adventure (3).

Sufism can be defined as Islamic mysticism, the mystical or spiritual dimension of Islam in which the individual seeks to find the truth of Divine love and knowledge through direct personal experience of God. Abu Hamid Al-Ghazali (one of the most prominent and influential eleventh-century philosophers, theologians and mystics of Sunni Islam) considered Sufism "as the best doctrine in comparison with philosophy or theology, because, while the human sciences are abstract and superficial, Sufism leads the learned to a positive knowledge of God and nature" (Campanini). Sufism leads to a closer and more intimate relationship with God and is "designed to establish the nature of humanity and of God and to facilitate the experience of the presence of Divine love and wisdom in the world" (Schimmel "Sufism"). Nasrollah Fatemi in his book, Love, Beauty and Harmony in Sufism (1998) defines Sufism as "an esoteric knowledge or simply a mystical way of reaching God and receiving His Divine Guidance and Blessing”, he states:

The purpose of Sufism is to enable man to realize his ability and dignity and to set his soul free from the shackles of ego, greed and prejudice. Sufism alerts man to the fact that the answers to his salvation are not outwardly religious pretensions. It reminds him to seek all that he needs within himself, to tear his attachment from the world of corruption, hatred and conflict. It removes man from his lowest state in order to reinstate him in his primordial perfection. In this stage, man is awakened to the true nature of the Creator, the nature of man and the spiritual values, which help man to become the total theosophy of God's attributes. (53) 
The above quotation highlights the main principles of Sufism that leads the Sufi to gain a true knowledge ( $m a^{\prime}$ 'rifa) of God and the nature of man. Sufism seeks to bring the Sufi closer to God not through reasoning and what the Sufi knows and sees, but the path of the Sufi is inside his own self. He must search inside himself; as the Qur'an commands: "And in yourselves. Then will you not see?" (Qur'an 51:21)

Sufism has its origin in the early days of Islam, its center located in Baghdad and Basra, which were then under the rule of the Abbasid Caliphate. Among the great Sufis who were also great poets are Fariduddin Attar (1145-1221), Umar Ibn al-Farid (1181-1235), Ibn Arabi (1165-1240), Jalal ad-Din Muhammad Rumi (1207-1273). These were Sufi thinkers first and poets second, yet their fame owes much to the beauty of their poetry. It is interesting to note that poetry is one of the most concise and effective expressions of the mystical experience. Spurgeon highlights the interconnectedness between poetry and mysticism, stating that "with the poets we find the most complete and continuous expression of mystical thought and inspiration" (11). Although mysticism is impalpable, through poetry it is possible to glimpse into the beyond. The consciousness of the Divine (which is ineffable) is the goal of the mystical experience. This experience finds its expression by using imagery and symbols drawn from the physical world. Jon Mundy states, "Like a finger pointing to the moon, poetical words and images offer us a lofty experience. Poetry combines imagery and feeling. It suggests something beyond the expected, preexisting belief or perception" (235).

\section{Altariq: The Path towards God}

As aforementioned, Sufism is the path of Islamic mysticism. Sufis have described the progress of the spiritual life as a journey or a pilgrimage. The Sufi who sets out to seek God calls himself a "traveler"; he goes through several "stages" along a "path" to the goal of reaching Reality (Haqiq'ah). The path consists of seven "stages", namely repentance, abstinence, renunciation, poverty, patience; trust in God, and satisfaction (Nicholson 21). The first stage on the path, repentance $($ tauba), means to regret previous wrongdoings and turn away from sins. The main duty of the Sufi is to act exactly contrary to the nafs, which in Arabic means the earthly part of the self, leading to disobedience due to desires and mortal ambitions. Every traveler on the path should purge the 
nafs of its evil attributes in order to replace these by pious qualities. The movement on the mystical path consists of a constant struggle against the nafs. For the nafs "is the cause of blameworthy actions, sins, and base qualities" and the struggle with it has been called by the Sufis Al-jihad $A L$ Akbar 'the greater Holy War"” (Schimmel Mystical Dimensions 112). ${ }^{1}$

In the second stage on the path, the Sufi has to increase in abstinence (wara ), caused by fear of God. The third stage, renunciation $(z u h d)$, means to give up this world, and eventually to give up everything that distracts the heart from God. In the fourth stage on the path, poverty, the Sufi renounces all worldly things for the sake of pleasing God. Sufis "are urged to this sacrifice by one of three motives: (a) Hope of an easy reckoning on the Day of Judgment, or fear of being punished; (b) desire of Paradise; (c) longing for spiritual peace and inward composure." (Nicholson 27) In the fifth stage, patience has three grades: patience in performing religious rituals, patience in discarding the desires, and patience in tribulations on the arduous path towards God. Besides, one of the most important stages on the path is (tawakkul), complete trust in God and self-surrender to Him. All Sufis believe that a traveler on a spiritual quest should first annihilate his nafs and become selfless. This is the stage of annihilation Fanaa'. It is only after the traveler has discarded his desires and the worries of the world, that he can approach God. The love of God will substitute all the needs he has once experienced, once he surrenders himself totally to God. In fact, this mystical path is described as the path of Divine love.

In Sufism, the path, often described as a journey; leads the traveler through several realms of the cosmos towards God. For Sufis, the journey imagery takes its significance from three paradigmatic journeys of the Prophet (Peace Be Upon him): his departure (Hijra) from Mecca to Medina, the combined experience of the Night Journey and Ascension; and the pilgrimage to Mecca that the Prophet $(\mathrm{PBH})$ undertook from Medina. Thus, I draw on Ibn Arabi's Sufi philosophy, which allows for a better understanding of the Sufi meaning of the journey in Moore's poems. Sufis in general and Ibn Arabi in particular, have been inspired by the Isra (Night Journey) of Prophet Mohammed. For Sufis, the Prophet's ascent symbolizes a spiritual journey towards God. The Prophet's experience of the Night Journey and Ascension has two parts. The Isra

\footnotetext{
${ }^{1}$ It is the greatest not the greater. Schimmel could not differentiate between the comparative and the superlative in Arabic.
} 
(Night Journey) is when the Prophet travelled from the Masjid al Haram in Mecca to Masjid al-Aqsa in Jerusalem. The Mi'raj (Ascension) is when the Prophet ascended to the heavens.

In relation to Ibn Arabi, amongst his works that clearly link to the Prophet's Night Journey are Kitab Al-Isra (The Night Journey), AlFutuhat Al-Makkiyya (Meccan Openings) and Kitab al-Isfar (The Secrets of Voyaging). In these works, the reference to the journey of Prophet Mohammed symbolizes a Sufi spiritual quest for the Divine. For Ibn Arabi, the journey to God is a continuous process that requires a passage through several spiritual openings. Ibn Arabi's Kitab al-Isfar revolves around his spiritual journey, the Prophet's Night Journey and the journeys of seven Prophets mentioned in the Quran. In the Preface to Kitab alIsfar, Ibn Arabi defines three different types of the journey: إن الأسفار ثلاثية They are the "لا رابع لها أثنتها الحق عز وجل و هي سفر من عنده، وسفر إليه وسفر فيه" voyage from Him, the voyage to Him and the voyage in Him." Prophets and Sufi seekers, in Ibn Arabi's view, are those who are "made to voyage by Him in Him." The "voyage" or journey in Him allows Prophets and Sufis to experience what Ibn Arabi called "spiritual openings" (2).

In Moore's poem "The Path," he depicts the different stages of the mystical path. The whole poem can be read as an allegory of the spiritual journey of the traveler from his original abode to God. Moore says:

You set out on foot

No snow will stop you

Shapes in the mist

Statues of warriors

Arms raised and weapons

You're undaunted

No footprints before you

You make your way (The Soul's Home 3-10)

In the above lines, Moore portrays a very painstaking image of the traveler on his way to seek God and receive His Divine love and knowledge, he is fearless and nothing will stop him from reaching his ultimate goal. The journey is hard and long. Moore illustrates various 
hardships on the path by alluding to them as ("snow", "shapes in the mist" and "statues of warriors"). Moore says:

A path like glass or amber

Cuts through the night like a flare

The black background of space dazzles

With its uncanny plethora of stars

Your heart's a steady beacon

Your forehead's an unwavering beam

It's not where you're going that's wonderful

But the glory of where you are

No light can compare with this brilliance

Nor description match its beauty (The Soul's Home 25-34)

Moore compares the path towards God to "glass", a simile that highlights the clarity of vision. The path is compared as well to an "amber stone" which is valued from antiquity as a gemstone and has been appreciated for its golden colour and its beauty. In ancient cultures, travelers used to carry the amber stone as they traveled long distance. They believed it held protective energies that guarded them against dangers on the road. Moore further compares the path to a "flare", a sudden burst of bright flame that illuminates the dark night with mysterious overabundance of stars. The traveler's heart is illuminated by Divine light, and it becomes "a steady beacon," a guiding light and his forehead becomes "an unwavering beam."

The consciousness of the Divine is the goal of the mystical experience. As it is ineffable, it cannot be understood or explained by any normal mode of perception. Schimmel explains that "Only the wisdom of the heart, gnosis, can give insight into some of its aspects" (Mystical Dimensions 4). For the Sufis, the nature of the heart is intellectual rather than emotional, as "the intellect cannot gain real knowledge of God" (Nicholson 69). God is "the Light of the Heavens and the Earth" and cannot be seen by the physical eye. He is visible only to the inward sight of the heart. The "vision of the heart" (ru'yat al-qalb) is defined as "the heart's beholding by the light of certainty that which is hidden in the unseen world" (Nicholson 39). When the heart is purged of sin and evil thoughts, the light strikes upon it and "makes it a shining mirror, so that the Devil cannot approach it without being observed" (Nicholson 39). Sufi poets derive much of their love for light imagery from the Quranic Verse of Light: 
Allah is the Light of the heavens and the earth. The example of His light is like a niche within which is a lamp, the lamp is within glass, the glass as if it were a pearly [white] star lit from [the oil of] a blessed olive tree, neither of the east nor of the west, whose oil would almost glow even if untouched by fire. Light upon light. Allah guides to His light whom $\mathrm{He}$ wills. And Allah presents examples for the people, and Allah is Knowing of all things. (Qur'an 24:35)

According to a mystical interpretation of the Verse of Light where the light of God is compared to a candle burning in a lantern of transparent glass, which is placed in a niche in the wall, the niche is the true believer's heart (Nicholson 50). Therefore, the believer's speech is light, his works are light, and he moves in light. Sufis have understood the inner meaning of this verse as a metaphor for the human heart, in which the Light of God resides and by which man is guided on his mystical path. Prophet Mohammed (PBUH), too, prayed that God would put a light into his ear and into his eye; "O Allah, place light in my heart, and place light in my hearing, and place light in my seeing, and place light beneath me, and place light above me, and light on my right, and light on my left, and place light behind me," after stating the different parts of his body, he concluded, "and make the light greater for me" (Sunan anNasa'i). The development of the theme of light is that of Abu Hamid AlGhazali's Niche of Lights (Mishkat al-Anwar), a theme later elaborated by Suhrawardi (1154-1191), a Persian philosopher and founder of the philosophy of Illumination (Ishraq). Suhrawardi provides a philosophical exposition of the journey of the soul that ends with illumination. Sufis speak of God casting a light into the heart by which the individual receives a higher form of knowledge. (Aminrazavi 16)

Moore elaborates further on the trope of light. In his prose poem, "Vision of the Shari'ah," written at the Prophet's Mosque in Medina, Moore writes that he had a vision of the Shari'ah, "as a giant, spectacular many-faceted chandelier of hundreds of prisms or lenses, a kind of glittering dome of raw starlight that fits down perfectly over the Haqiq'ah (Sacred Truth). Its light shines out from each lens beaming the light for every aspect of our lives." (Sparrow on the Prophet's Tomb 147) Though the essence of Sufism is the journey to God, Sufis consider Shari'ah as largely complemented by Islamic Way (Tariq 'ah) to help the seeker in his search for Reality (Haqiq'ah). Initially, Shari'ah is an external body of rules. But when the Sufi practices the rules of the Shari'ah in his life, he discovers that Shari'ah becomes a personal realization for him. In this way, the Shari'ah and the Sufi's journey toward God are intimately linked to each other. Shari'ah awakens the Sufi's true nature, and by following its rules, he reaches the final stage of the path. According to William 
Chittick, Sufis understand Shari'ah, as "embracing knowledge and all the theoretical teachings of Islam...the Reality or Haqiq'ah is the inward states and stations attained by the traveler in his journey to God and in God" (The Path of Love 10).

Moore's poem "Some Flashlight Beams" is a dialogue between the poet / the traveler and his Shaykh (spiritual master). It highlights the metaphorical path towards God. The poem opens with the dialogue:

Turn it on."

"Here, take this flashlight. If it gets any darker

"It can't get any darker. It's night."

"The beginning of the world was darkness.

The end of the world is light."

"And what is in between them coils and turmoil,

Mountain upheavals, rainbows breaking into falling

Debris, earthquake, flood and firestorms? Blight?" (The Blind Beekeeper 1-9)

The traveler is asked to take a flashlight with him on his journey, as it is dark night. The repetition of the word "dark" emphasizes the state of ignorance of the traveler before he starts the journey. The word "night" connotes darkness, sinfulness and a time of obscurity. There is juxtaposition in this line "the beginning of the world was darkness / the end of the world is light" that accentuates the contrast between the two key words in the title: the path and the love, and further reveals the Sufi concept of the journey from ignorance to knowledge; from evil to piety, and from darkness to light. The mystical path is arduous and wearisome. Moore states:

"It begins in utter blackness. Planets emerge. There's

Starlight. Then anguish and death. Torture and

pain. But it ends in light.

Meanwhile take this flashlight

If it gets any darker, turn it on.

But when light comes, add yourself

To the light" (The Blind Beekeeper 24-35)

The Sufi suffers tribulations showered upon him. The Shaykh (spiritual master) tells the Sufi / the traveler that he will suffer from "anguish and death" and "torture and pain" but at the end of the journey, there is light. The word "flashlight" is a metaphor that refers to the different stages on the path towards God. The last line highlights the quest of Divine light as the ultimate goal of the traveler. Once he/she traverses the path to this Last Reality, an inner light will lead him/her. This light becomes stronger 
as travelers free themselves from the attachments of this world and the light polishes the mirrors of their own hearts. Only after a long period of purification, will they be able to reach illumination, where they become endowed with Divine love and knowledge. From there they may reach the last stage of the mystical path. Schimmel describes this as the "lifting of the veil of ignorance" (Mystical Dimensions of Islam 4).

\section{Futuh: The Openings of Doors}

The Sufi concept of "opening" is central to Moore's poetry. Reading his poem "When the Door Swings Open," from his collection The Soul's Home reveals the influence of Sufism on Moore's poetry. Ibn Arabi and Sufis in general employ the expression of doors in order to show the "openings" that give access to Divine Truth. The Sufi in his quest for the Truth knocks on doors that open when an experience of Kashf and spiritual realization takes place. In a similar way, Ibn Arabi speaks of the way the traveler is in a constant search of "openings" that allow him to reach God. In Ibn Arabi's words:

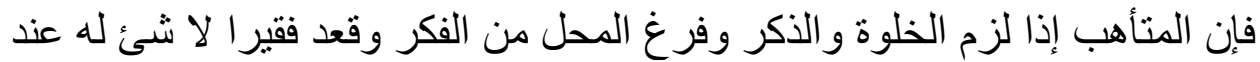

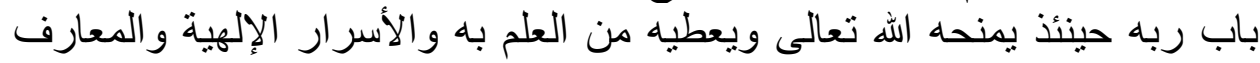

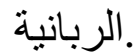

When the traveler adheres to retreat and remembrance of God, when he empties his heart of thoughts, and when he poorly sits at God's door with nothing, then God will bestow upon him and give something of Him, the divine mysteries and the divine knowledge. (Futuhat I: 31.4)

The Sufi, by undertaking a journey of inner retreat (khalwa), which is seclusion from others in order to devote oneself fully to meditation, and knocking on God's sacred door, is enabled to experience "openings" or unveiling of the "divine mysteries." William Chittick in his definition of the meaning of "opening" (futuh) in Ibn Arabi's Sufi thought refers to the symbol of door as:

A mode of gaining direct knowledge of God and of the unseen worlds without the intermediary of study, teacher or rational faculty. God "opens up" the heart to the infusion of knowledge. The word "opening" suggests that this type of knowledge comes to the aspirant suddenly after he had been waiting patiently at the door. (The Sufi Path of Knowledge xii)

William Chittick highlights that for Ibn Arabi, effort can take seekers only as far as the door. Having reached the door, they can knock as often as they like. It is God who will decide when and if he will open the door 
(Ibn Arabi 14). This explains the meaning of the word "opening" (futuh) in the title of Ibn Arabi's The Meccan Openings (Futuhat Al-Makkiyya). The title reveals that the knowledge contained in the book was not gained by reasoning. Yet, knowledge (ma'rifa) was endowed upon Ibn Arabi when God opened the door to him. In other words, the whole The Meccan Openings (Futuhat Al-Makkiyya) represents a series of unveilings and witnessing, or mystical visions. Chittick points out that "It is important to keep in mind that Ibn Arabi does not confuse unveiling, witnessing, and opening with "revelation," which applies properly to prophetic knowledge" (Ibn Arabi 15).

In his poem "When the Door Swings Open," Moore highlights this last stage in the Sufi path, when the traveler surrenders himself totally to God and the door opens, signaling the spiritual "openings" that the traveler encounters at the end of the journey. Moore says:

When the door swings open

Who do we see

In the eyes of the clouds?

Oh hallowed be thy name

Unsounded except in every sound

Unseen except in every sight

Unthought and Unthinkable except in every

Unthinkable thought thought and still

Thinking on

We proclaim you

Stairways come down to

Catch us up

Fish stick their snouts out of water

Wings fill skies both seen and unseen

From earth to heaven (The Soul's Home 1-3, 9-21)

In the above lines, Moore highlights the last stage of the spiritual journey towards Truth. God is "the Light of the Heavens and the Earth". God cannot be seen by the physical eye. He is visible only to the inward sight of the heart. When the aspiring traveler adheres to the remembrance of God's name, when he empties his heart of imperfections and turns away from sins, when he gives up everything that distracts his heart away from God, when he annihilates his ego and becomes selfless, then God will bestow upon him something of His Knowledge. Before the Sufi reaches opening, he will have to seclude himself from people through inner retreats. Finally, Moore writes, "We proclaim you / stairways come down to / catch us up." In these lines, he compares the mystical path to a ladder, 
a staircase that leads to heaven, on which the traveler slowly and patiently climbs towards higher levels of experience. A stairway to heaven is a spiritual ladder, a symbol of spiritual evolution. Lastly, by engaging in the norms of the Shari'ah and the Tariq'ah and undertaking a journey of inner retreat, the traveler is allowed to experience an "opening" of the door, beyond which lie the "divine mysteries."

\section{Dhikr: The Remembrance of God}

Dhikr, remembrance, is a practice that is meant to result in Futuh "the openings of doors" and a sacred meditation of the heart and one of the essential Sufi practices that helps man to access the light of love within the heart. Dhikr is often encouraged in the Qur'an, where it means keeping God in mind and mentioning or invoking his name. Ibn Arabi draws the meaning of Dhikr from the Qur'an, where the concept is repeatedly used: "and remember Allah often that you may succeed" (Qur'an 62:10), “So remember Me, I will remember you," (Qur'an 2:152) and the Quranic verse "Those who have believed and whose hearts are assured by the remembrance of Allah. Unquestionably, by the remembrance of Allah hearts are assured". (Qur'an 13:28) Remembrance is keeping God in mind at all times and in all activities. Ibn Arabi defines it in this sense as" حضوره مع المذكور" "presence with the One Remembered" (Futuhat IV 36.8).

Moore maintains that Dhikr is an Arabic word that has a cluster of meanings: "recollection, remembrance, reminiscence, commemoration, naming, mentioning, invocation of God, mention of the Lord's Name, and (in Sufism), incessant repetition of certain words or formulas in praise of God, often accompanied by music and dancing" ("Dhikr, a Door that when knocked, opens" 57). Schimmel defines Dhikr as, "the recollection of God, during which not only the tongue, and then the heart are filled with the name of God, but the whole body of the meditating Sufi is permeated so that his blood and each of his limbs is replete in the name of God and practices, as it were, its own Dhikr." (As Through a Veil 28) Hence, Dhikr is a strong pillar in the path toward God because nobody can reach God without constantly remembering Him. Schimmel remarks: "concentrated recollection sets free spiritual energies that provide help in the progress on the Path" (Mystical Dimensions 167). Ibn Arabi speaks of Dhikr as knocking at God's door in the hope that God will open it. $\mathrm{He}$ 
defines Dhikr as"الحضور و المر اقبة لآثاره سبحانه في قلبك وفي العالم "presence and watchfulness over God's traces in the heart and in the cosmos" (Futuhat III 502.12). It is to be with God, to recognize him through his signs and manifestations in the cosmos and the self. Ibn Arabi says: "Occupy yourself with dhikr until the world of imagination is lifted from you and the world of abstract meanings free of matter is revealed to you. Occupy yourself with dhikr, remembrance, until the Remembered manifests Himself to you..." (Journey to the Lord of Power 36) Ibn Arabi's writings on remembrance provide some insight when reading Moore's poetry. Ibn Arabi emphasizes the intersection between the Dhikr of God and the attainment of illuminative knowledge. In order for "darkness" to be dispelled from the heart, the seeker recites the words of God, remembers His names in the hope of reaching the Sacred Light.

This Sufi principle is highlighted in Moore's poem "The Joys of a Breath" published in The Soul's Home (2014). Moore employs several images throughout the poem to reincarnate the joys of breath filled with remembrance of God to different joyful creatures who seem to be equally guided by their creator: to golden fields where the grasses are all bending in one direction, the flight of parrots towards sunlight, and the sudden joy felt by all people on earth at the same time. The repetition of the $/ \mathrm{F} /$ sound in "filled" and "field", along with the assonance and the consonance help to create such harmony between man and nature that Dhikr allows, recalling the Quranic verse, "The seven heavens and the earth and whatever is in them exalt Him. And there is not a thing except that it exalts [Allah] by His praise, but you do not understand their [way of] exalting. Indeed, $\mathrm{He}$ is ever Forbearing and Forgiving." (Qur'an $17: 44)$

The joys of breath filled with

Remembrance of God

Is field after field of golden pastureland

The grasses all bending one direction

The flight of a few thousand parrots

Through dark red canyons in shadow

Bursting into a blue sunlight

Of everyone on earth at the same time

Going about their business

And suddenly feeling joy 
Moore is adept at originating images, which add freshness and vitality to his poetry. The metaphors, here, are original and demonstrates his creativity. The diction that he chooses has a profound effect on the poem. The "golden" colour denotes success, achievement and triumph. Moore uses "the flight" as a metaphor for spiritual experience. The word "parrots" is symbolic of the soul and the word "bursting" denotes the sudden and violent movement of the parrots. In effect, the imagery of flight and birds has long been a universal symbol of the ascension of the human soul to a higher reality. Mystics of all religions have long used birds to symbolize the flight of the soul up to heaven. However, as Ali Asani notes, "no other tradition of mysticism has developed as elaborate symbolism and imagery related to bird as Sufism" (qtd. in Foltz). Bird imagery appears in the work of almost every Sufi poet, the best-known example is the Conference of the Birds by Fariduddin Attar, an epic poem of nearly five thousands couplets.

There is a contrast between "dark red canyons" and blue sunlight" to highlight the ascension of the soul from darkness of the world to Divine light. The poem sets up the contrast between the two colours to enhance their opposite meaning. "Red" is the colour of violence, danger and anger, whereas, the colour "blue" symbolizes faith, truth, and heaven. The gist of the poem is that by remembering God all the time, God's love will eventually flood the Sufi, "for its flood flashes through village and metropolis." This particular line echoes a line from Moore's spiritual teacher, the Moroccan Sufi Muhammad Ibn al-Habib, who states in his


the breath of God's remembrance was to fill the west / and there was a sick man in the east, he would be cured of his harm."

Another poem that highlights the mystical path and the influence of Divine love and remembrance is "Lambs and Lions." The poem echoes William Blake's pair poems "the Tyger" and "the Lamb" from his collection Songs of Innocence and Experience. In "Lambs and Lions," the lamb is typically a sacrificial animal, (In Islam, Prophet Ibrahim's sacrifice of a ram in place of his son, Ismail) and symbolizes gentleness, innocence, and purity. The opening question: "Are Lambs that ask the way to heaven / the same as lions?"(1-2) enacts what will be the single dramatic gesture of the poem, and each subsequent stanza elaborates on this conception. Moore writes:

One has eyes that never leave the ground The other's heads held high in the sky's bright sunlight 
One quiet as a mouse and soft as a cloud

The other's mane like fire and teeth like death

Do they trod the earth the same and

Leave the same trail behind them? (The Soul's Home 3-8)

Since they represent opposite ideals, using juxtaposition highlights their differences. The title "Lambs and Lions" already sets up the idea of comparison. Moore compares the lamb to "a mouse" and "a cloud" in its quietness and softness. In addition, the lamb symbolizes sweetness, forgiveness and meekness. On the other hand, the lion's "mane is like fire" and "teeth like death." The lion is the symbol of the brave man; Ali Ibn Abi Talib, the cousin of Prophet Mohammed, was called "God's Lion." In fact, the poem introduces a literal juxtaposition of the two animals (the lambs and the lions). The speaker wonders "Do they trod the earth the same and / Leave the same trail behind them?" The Sufi (whether he is a lion or a lamb) has to purify his heart from all impurities of the world and seeks to find the truth of Divine love. As the poem progresses, the speaker answers his question, he says:

Lions and lambs both land in God's land at last

Enwrapped together in the circle of His love

Baaing and roaring become perfect murmurs

All eternity long (The Soul's Home 20 - 23)

The significance of the influence of Divine love is seen in the peaceful communion of the lions and the lambs. They both represent the soul. They are both enwrapped by Divine love and the "baaing" of the lambs and the "roaring" of the lions become "perfect murmur" of the greatness of God. In effect, the remembrance of God will help the Sufi to attain purity and cause his outward form to be adorned with Divine love. The power of love is overwhelming. This love "can carry the mystic's heart to the Divine Presence 'like the falcon which carries away the prey,' separating him, thus, from all that is created in time" (Schimmel Mystical Dimensions of Islam 4). For Moore, Love, in essence, is a spiritual remedy capable of healing and cleansing the imperfections of the soul. Moreover, love can be expressed in different forms; in the mental and spiritual forms and in the physical form, which consists in the performance of devotional activities of the remembrance of God.

\section{The Miracle of Suffering \& Purification}


Moore's belief in the need for spiritual purification as the way to illumination accords with the principles of Sufism. Suffering is the pain of purification, cleansing the heart of imperfections. Through suffering, the traveler learns to surrender to God and becomes His slave. He accepts all kinds of tribulations that are showered upon him. Schimmel maintains, "Divine love makes the seeker capable of bearing, even of enjoying, all the pains and afflictions that God showers upon him in order to test him and to purify his soul" (Mystical Dimensions 4). It is worth mentioning that a Hadith about suffering is very common among the Sufis, it states that the most afflicted people are the prophets, then the saints, and then so forth. The Hadith was narrated from Mus'ab bin Sa'd that his father, Sa'd bin Abu Waqqas, said: "I said: 'O Messenger of Allah, which people are most severely tested?' He said: 'The Prophets, then the next best and the next best. A person is tested according to his religious commitment. If he is steadfast in his religious commitment, he will be tested more severely, and if he is frail in his religious commitment, his test will be according to his commitment. Trials will continue to afflict a person until they leave him walking on the earth with no sin on him."” (Sunan Ibn Majah)

The prophets, being nearest to God, have to suffer most, as is shown in many stories in the Qur'an. The transformation of the soul through suffering and painful purification is often expressed in the imagery of "alchemy", an ostensibly magical process of transformation or creation. (Mystical Dimensions 4-5) This image is defined as the process of taking something ordinary and turning it into something extraordinary, sometimes in a way that cannot be explained. Similarly, William Chittick describes the spiritual path of the traveler to be an alchemical transmutation of "the base copper of his substance into pure and noble gold' (The Path of Love 11). In his poem "Piece of Coal", Moore writes:

The piece of coal that wanted to be diamond said to the earth: Press me.

The succulent grape that wanted to be wine said to the feet: Crush me.

The cloud that wanted to be thunder and rain said to a facing cloud: Collide with me.

The mountain that wanted to be level valley said to the elements: Erode me.

The oyster that wanted to produce a pearl said to a sand-grain: Irritate me.

The heart that wanted to be filled with light said to the world: Break me. (The Blind Beekeeper 1-12) 
Moore skillfully presents several images of transformation to highlight the significance of suffering for the purification of the heart. The soul accepts every "tribulation" that is showered upon it. Just as a piece of coal is changed into a diamond by high pressure; just as grape juice is purified by the constant "tribulation" of fermenting until it becomes pure wine; just as the clouds change to storm and thunder by colliding; and just as an oyster magically creates a pearl by asking a grain of sand to irritate it; the human soul can mature only through suffering. The Sufis accept willingly all kinds of tribulations, which are regarded as signs of special kindness from God. As Schimmel maintains, "tribulations and afflictions are a sign that God is near." She emphasizes, "This indulgence in suffering...the feeling of affliction is the fastest steed to bring man to perfection" (Mystical Dimensions 137). The imperative commands ("press", "crush", "collide", "erode" and "irritate") suggest the transformation from one state to another. Dali Lama once said, "When everything is falling apart, something else is trying to be born" (qtd. in Mysticism and Miracles 220). Moore writes:

O our lives cry out to be pressed to

diamond, call out to be

crushed to wine, sing out to be made to

fall as merciful rain all around us,

Our mountains cry out to be worn down

to passable valleys

So we can fill those valleys

with heart's light

For other travelers

to see by (The Blind Beekeeper 33-42)

In Moore's poem "If It's a Butterfly Poem You Want", he depicts the metamorphosis that the Sufi has to pass through, the finding of a "way out" of illusion or a "way back" to absolute Truth. The butterfly has complete metamorphosis. Moore painstakingly represents the image of the butterfly flapping its wings quickly and lightly. The butterfly is a metaphor for the soul, which returns to God. Moore depicts the power of the wing to lift the soul through flight to paradise. He writes:

If it's a butterfly poem you want flattering the air with its

Flat-winged fluttering cutting its own eccentric zigzags through

What's nothingness to it straight ahead and just onward angle-flap by angle-flap

Heading to nectar Oh sweet-hearted companions of the wavering and Wavy way each wave-length a winged soul message pulling us from our 
Deep most green insideness in the sweet jig-jag splendors of His Incandescent love (The Soul's Home 1-8)

Moore addresses his Sufi whirling companions telling them how the butterfly nectars "a winged soul message" pulling them from the darkness of the cocoon to Divine love. Butterfly symbolism includes its visible qualities of grace and beauty. Werness states: "Because of its light, airy flight, and its dramatic life cycle, the butterfly is nearly universally a symbol of the human SOUL and of immortality." Werness adds, "Its brilliant colors and flickering flight link it to the sun, light, and ascent into the spiritual realm. Its delicacy expresses the fragility of life and the fleet passage of time and pleasure."

In fact, the image of the butterfly is one of the most important symbols in Sufi poetry. The butterfly and the nightingale both are soul symbols. Whereas, the nightingale symbolizes the soul longing for God, the butterfly symbolizes the soul, which, through suffering and purification, reaches absolute Truth, the ultimate goal of all Sufi. The spiritual meaning of "butterfly" is the endless cycle of life. It is a symbol of powerful transformation. Its life cycle begins when it is hatched from an egg. It lives as a caterpillar immediately after hatching and later retreats back into the cocoon where it goes through a transformation. In the last stage, the cocoon opens. Soon a very colorful butterfly comes out of the darkness. The transformational stage of the butterfly holds many mysteries, but what emerges is a beautiful creature. For the mystic on the Sufi path, transformation is inevitable. God brings healing for the soul. There are imperfections in the heart. When enclosed in Divine love, these imperfections are cleansed and "His Incandescent love" guides the Sufi through doorways that lead him to know more about God.

Moore in his poem "The Miracle of Pain," wonders why "spiritual pursuit" is so associated with "physical pain". He mentions three different situations related to three sacred beliefs, Islam, Christianity and Buddhism. The first situation is about Abd al Qadir Jilani, the founder of the Qadiri order. His concept of Sufism was that of a jihad waged against one's own will in order to overcome selfishness and worldliness and to submit to God. Moore says that Abd al Qadir Jilani used to "tie his hair to a nail on the wall to / snap his head back if he dozed off / reading Qur'an." The second situation is about Christian mystics who endure endless difficult permutations of such as "spontaneously bleeding from the / wounds of Christ." The third situation is 
Sitting in Buddhist meditation on puffy black cushions

Cross-legged for hours to

Focus the mind nearly

Drove me up the wall I was facing. (Sparrow on the Prophet's Tomb 13-16)

Before his conversion to Islam, Moore was influenced by Buddhism. Meditation is one of the most important practices in Buddhism, because it provides insight, quietness of mind, temporary reprieve from suffering, inner peace, and helps one on the path to enlightenment. However, it requires physical effort in order to achieve the spiritual ecstasy. In the three different situations mentioned by Moore in the lines above, the mystic suffered physical pain in order to achieve illumination. Moore says:

Birth is no picnic. Death often

less so. Life in between: a

tough love event.

Yet it all brings us to God.

These blisters on feet around

Kaa'ba marble

around and around,

the headache that comes from

odd short hours of

sleep in order to

wake up the heart before Allah in the

last watches of the night-

the abode of lovers-

is the price to pay for ma'rifa- (Sparrow on the Prophet's Tomb 17-30)

In the above lines, Moore states that blisters and headaches he suffered from are the price to pay for "ma'rifa," knowledge of God. The physical pain and suffering are the price the traveler has to pay for acquiring Divine knowledge and love. Moore painstakingly portrays intense images of the metamorphosis of the traveler. He adds:

As all creatures of this earth must

crack open the shells on acorns or mussels to get

the meat, the

earth splits apart revealing

deep fissures of ruby, whole

generations drown and later generations

come- $\mathrm{a}$ 
tear of joy forms in the eye of one

who sees The One Who

Sees! (Sparrow on the Prophet's Tomb 31-40)

Moore adeptly presents striking images that highlight the metamorphosis of the Sufi / the traveler. In order to get the meat of "acorns", the nuts of the oak tree, or "mussels", the shellfish, one has to crack open the hard shells that close tightly together. Earth splits and deep fissures of ruby are revealed, generations are drowned and other generations are born. In the last line, Moore says that "a tear of joy forms in the eye of one / who sees The One Who Sees!" At the last stage on the path, the traveler will achieve the spiritual ecstasy and a tear of joy forms in his eye. The traveler sees God by the inward sight of his heart. When the traveler purges the nafs of its evil thoughts, when he gives up everything that distract the heart from God and surrenders himself totally to God, then he will be able to reach illumination of Divine Reality.

\section{From Darkness to Light: A Conclusion}

Daniel Abdal-Hayy Moore was an eminent American Sufi poet. Sufism was the very centre of his being, it was the flame, which fed his whole life; and he was intensely and supremely thrilled as he was soaked in Sufism. His poetry represents an endless yearning for the Beyond and conveys the marvelous experience in the mystical path towards God and the various stages the traveler has to traverse. For Moore, Sufi poetry has been a form of remembrance, a way of connecting more deeply with God. Reading his poems in the light of Ibn Arabi's theosophy has revealed the intimate connection between his poetry and the principal tenets of Sufism. The imprints of Ibn Arabi's ideas have been found in Moore's poems that are selected to clearly depict the mood underlying his poetry. Ibn Arabi's concept of "opening" futuh that gives access to Divine Truth is central to Moore's poetry. For Moore, "opening" is a synonym for several other terms, such as unveiling, divine self-disclosure, witnessing, and insight. In his poetry, he shows that by following the rules of the Shari'ah and the Tariq'ah and undertaking a journey of inner retreat, abstinence, renunciation, prayer, constant remembrance and annihilation, the poet/the Sufi/the traveler is allowed to experience "opening" of the door or unveiling of the "divine mysteries." Dhikr or remembrance is another Sufi concept, which can be traced in Moore's poems. For Moore, to remember God is to awaken the innate understanding of the Transcendence of God. Moore reveals the intersection between the remembrance of God and the realization of illuminative knowledge. In order for darkness to be dispelled from the traveler's heart, he remembers God's names in the hope of reaching His sacred Light. For Moore, poetry 
is a form of remembrance (Dhikr) with transformative capabilities and its main objective is illumination.

Moore's poems depict the labyrinths of spiritual experience that the persona traverses in quest of Divine love through symbolic expressions. He has shown an extraordinary genius for indirect and suggestive imagery, artistic oblique representations of the Sufi's knowledge of the Truth. His poetry is imbued in images and symbols that reveal and develop the Sufi experience such as the journey, the light and the alchemy. Finally, Moore's poetry highlights the quest of Divine light as the ultimate goal of the traveler. His poetry intensely depicts the Sufi path of love and the spiritual journey from darkness to the Divine light of God.

\section{Works Cited}

Al-Ghazali. Revival of Religious Learnings. Translated by Fazl al-Karim, Vol.

4. Islamic Philosophy online, 2003. Http: //ghazali.org/ihya/english/ihyavol4-C5.htm. Accessed 1 September 2018.

Aminrazavi, Mehdi. Suhrawardi and the School of Illumination. Routledge, 1996.

Campanini, Massimo. “Al-Ghazali”. https://www.ghazali.org/articles/gz2.htm.

Accessed 1 September 2018.

Chittick, W. The Sufi Path of Love: The Spiritual Teachings of Rumi. Albany: University of New York Press, 1983.

---. The Sufi Path of Knowledge. Albany: University of New York Press, 1989.

---. The Self-Disclosure of God: Principles of Ibn al-Arabi's Cosmology. Albany: University of New York Press, 1998.

---. Ibn Arabi: Heir to the Prophets. Oxford: One world Publications, 2005.

---. The Sufi Doctrine of Rumi. Bloomington: World Wisdom, 2005.

Cornell, Vincent J. Voices of Islam. Greenwood Publishing Group, 2007.

Dhar, A. N. Mysticism in Literature. Atlantic Publishers and Distributors, 1985.

Edward E. Curtis IV. Encyclopedia of Muslim-American History. 2-Volume Set, Facts on File, Inc., 2010.

Fatemi, Nasrollah. Love, Beauty and Harmony in Sufism. NY: A.S. Barnes \& Co. Inc., 1998.

Foltz, Richard. Animals in Islamic Traditions and Muslim cultures. One world Publications, 2014.

Gril, Denis. "The Journey through the Circles of Inner Being according to Ibn Arabi's Mawaqi' al-nujum". The Muhyiddin Ibn 'Arabi Society. 
http://www.ibnarabisociety.org/articles/journeyofbeing.html. Accessed 5 September 2018.

Ibn al-Habib, Muhammad. The Diwan of Shaykh Muhammad Ibn al-Habib: The Desire of Journeying Murids and the Gift to Wayfaring Gnostics. Iqra Agencies Ltd. 2017

Ibn Arabi, M. The Bezels of Wisdom. Translated by Austin, W. J. New York: Paulist Press, 1980.

---. Journey to the Lord of Power. Translated by Harris, R. T. London and The Hague: East West Publications, 1981.

https://archive.org/stream/JourneyToTheLordOfPower. Accessed 15 September 2018

--- Kitab al-Isfar. http://www.sufi.ir/books/download/arabic/ibnarabi/isfaarasfaaribnarabi.pdf Accessed 2 October 2018.

---. Futuhat al-Makkiyya. http://shiaonlinelibrary.com/

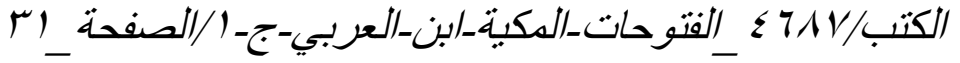

Jaffray, Angela. "Unveiling from the Effects of the Voyages" An Introduction to the Kitab al-Isfar. The Muhyiddin Ibn 'Arabi Society.

http://www.ibnarabisociety.org/articles/alisfar_introduction.html Accessed 5 September 2018.

Jamal, Mahmoud. Islamic Mystical Poetry: Sufi Verse from the Early Mystics to Rumi England: Penguin Classics, 2010. Google books.

Lewis, Franklin D. Rumi: Past and Present, East and West. Oxford: One world Publications, 2000.

Lewis, C. Day. The Poetic Image. Bloomsbury Publishing PLC. 2011.

Mattawa, Khaled. "Writing Islam in Contemporary American Poetry: On Mohja Kahf, Daniel Moore, and Agha Shahid Ali." PMLA, vol. 123, no. 5, 2008, pp. 1590-1595. JSTOR, www.jstor.org/stable/25501962. Accessed 1 November 2018.

Moore, Daniel Abdal-Hayy. The Soul's Home. Philadelphia: The Ecstatic Exchange, 2014.

---. Sparrow on the Prophet's Tomb / Poems. Philadelphia: The Ecstatic

Exchange, 2009.

---. The Blind Beekeeper. First Printing Edition, 2001.

---. "Dhikr, a Door that when knocked, opens." Voices of Islam VII, pp.53-70.

---. "Choosing Islam: One Man's Tale."

http://ecstaticxchange.com/2015/06/25/choosing-islam-one-mans-tale/ Accessed 5 September 2018.

---. "The Ecstatic Exchange: Words on My Life and Poetry" http://ecstaticxchange.com/2010/09/29/the-ecstatic-exchange-words-onmy-life-and-poetry/ Accessed 5 September 2018. 
---. "Extended Biographical Information"

http://ecstaticxchange.com/2015/06/22/5885/ Accessed 5 September 2018.

---."Q-News Interview / a Sweet Interrogation"

http://ecstaticxchange.com/2015/04/11/q-news-interview-a-sweetinterrogation/ Accessed 5 September 2018.

Mundy, John. A course in Mysticism and Miracles. Weiser Books, 2018. Google Books.

Needleman, Jacob and Mehdi Aminrazavi. Sufism and American Literary Masters Sunny Series in Islam State University of New York Press, 2014.

Nicholson, Reynold A. The Mystics of Islam. Library of perennial philosophy: Spiritual classics. Routledge, 1999. Online Book. http://www.sacredtexts.com/isl/moi/moi.htm. Accessed 1 September 2018.

Qur'an. King Saud University's E-Quran. http://quran.ksu.edu.sa/

Renard, John. Historical Dictionary of Sufism. Maryland: Rowman \& Littlefield Publishers. 2015.

---. The A to Z of Sufism. The Scarecrow Press, 2009.

Sandburg, Carl. The People, Yes. London: Houghton Mifflin Harcourt, 2015.

Schimmel, Annemarie. The Triumphal Sun: A Study of the Works of Jalaloddinn Rumi. London: East-West Publications, 1980.

---. As Through a Veil: Mystical Poetry in Islam. New York: Columbia University Press, 1982.

---. Mystical Dimensions of Islam. Chapel Hill: University of North Carolina Press, 2011.

---. "Sufism." Encyclopedia Britannica.

https://www.britannica.com/topic/Sufism Accessed 15 August 2018.

Spurgeon, Caroline F. E. Mysticism in English Literature. BiblioLife, 2008.

Sunan an-Nasa'i. https://sunnah.com/nasai/12/93 Vol. 2, Book 12, Hadith 1122

Sunan Ibn Majah. https://sunnah.com/ibnmajah/36/98

Underhill, Evelyn. Mysticism. texts.com/myst/myst/index.htm. Accessed 1 September 2018.

Werness, Hope B. Continuum Encyclopedia of Animal Symbolism in World Art.

Continuum International Publishing Group, 2007. Google Books.

Wilson, Colin. Poetry and Mysticism. City Lights Publishers, 1986. 